\title{
Digital Storytelling: Engaging Young People to Communicate for Digital Media Literacy
}

\author{
AMBIGAPATHY PANDIAN \\ Universiti Malaysia Sarawak \\ SHANTHI BALRAJ BABOO \\ LIM JING YI \\ Universiti Sains Malaysia
}

\begin{abstract}
Digital stories are powerful forces in the lives of young people as they shape opinions, assumptions, and biases about the knowledge of everyday lives. This paper presents the findings of an exploratory project that saw secondary school students participating in a digital storytelling project. Underpinning this project was an interest in cultivating digital media literacy among young people. Data analysed included a self-assessment questionnaire, focus group discussions with young people and the production of short 1-3 minute digital stories on various issues related to online cultures. The first part of the article looks at the digital competences of young people. The findings of a self-assessment revealed that the respondents felt generally capable when working with information, and moderately capable of communication and safety but had difficulty with content creation and problem-solving skills. The findings of the second part of the study revealed that young people get much enjoyment and feel smart and knowledgeable as they scroll quickly through an online search on information, images, news, and stories. They are content consumers and content creators who enjoy dramatic engagements and can produce stories as communication texts. However, it was also found that the students confronted difficulties in evaluating the relevance and usefulness of information as well as in expressing their ideas through different modes of visual communication. By way of conclusion, this paper calls for the creation of a state-based advisory committee composed of educators, researchers and media practitioners who will work towards building digital media literacy.
\end{abstract}

Keywords: Digital storytelling, young people, schools, digital media literacy, competences.

\section{INTRODUCTION}

Young people today confront a dramatic mediatised world, rich with opportunities and risks, as they interact and participate in cultures that construct a diverse world of social realities. They seek information and entertainment instantaneously, communicate with friends, engage in social and political activities and participate in social networks. They weave stories and images that tell us about their perceptions and beliefs, relationships, choices and decisions that they take in their everyday tasks.

Living in wired and hyper-connected cultures like this would not only require using a wide range of digital devices but also consciousness in working towards developing critical and responsible thinking skills as active and informed citizens. In this regard, the focus on digital competences and digital storytelling are pivotal to productive participatory cultures in society so that young people can respond to complex communications environments in ethical and mindful practices. Digital storytelling specifically promotes the vital role that user choice and responsibility play in the new online environments. The focus on cultivating digital storytelling competences here supports literacy goals in empowering young people with 
capacities that enable them to engage effectively - the ability to access, analyse and create communications in today's increasingly digitised society.

\section{PROBLEM STATEMENT}

The focus on digital media literacy becomes a concern when young people are immersed in cybercultures without holistic understandings of knowledge, skills, values, and responsibilities. It is not clear how spaces in schools are built to engage young people with digital media activities. Much has been discussed about the gaps in schools settings where online practices among students are not delved as analyses of critical and creative learning and communication (Jones, 2010; Guo, 2014; Shanthi et al., 2017; Prasad et al., 2017; Shanthi et al., 2015). Worse still, the digital generation is assumed to be a group of young people who are super-users of digital content and highly competent in their use of digital technologies (Shanthi, Ambigapathy, Prasad \& Aaron, 2013).

This project opens spaces in secondary schools to assess students' digital competences and to explore the ways that they can engage in digital media literacy activities in productive ways. The outcome from collecting and gathering data on young people's media practices will enable policymakers, practitioners and civil activists to identify and map key trends in thinking about citizenry and digital participatory cultures. This article is written to enhance discussion on digital storytelling which is still largely uncharted territory and to move this approach as a pathway of digital media literacy practice in schools.

\section{OBJECTIVES}

The present study was interested to advance digital media literacy in school settings with a focus on students' competences in five areas: information, communication, content creation, safety, and problem-solving. In connection with this, the study was also concerned with digital storytelling to explore students' competences in using digital ways to use media as a tool for civic engagement.

\section{RESEARCH BACKGROUND}

Studies focusing on digital competences and digital storytelling hold an important place in Malaysian research on young people, specifically in the creation and sharing of their stories. For many years, parental involvement was important in supporting young people's literacy (Johnson, 2015) as they were the key storytellers, facilitating the understanding of their surrounding world. Today, the Internet and the media have become the popular storytellers, imparting narratives about everyday living. This, in turn, has led to new forms of storytelling, specifically in digital worlds. Posting status updates, photos, videos, blog posts or podcasts online have become core activities for many young people in contemporary world realities (Juppi, 2017; Cohen \& Mihailidis, 2013; Hobbs, 2011; Livingstone, 2004). It is therefore essential to respond quickly to the role of digital media literacy in today's hyper-connected cultures to gain insights on information access, communication possibilities, the many forms of media messages and participatory cultures encountered in everyday life. This is crucial in understanding the ways young people engage new media environments in molding perceptions and beliefs, in making personal choices and in motivating their participation in communication and media cultures. 
Digital Media Skills Among Young People

Livingstone (2011) raises the concern of digital media literacy in developing critical abilities necessary to function as enlightened citizens and consumers in a mediatised society. She notes the need to assess the capacity of young people in using and making sense of media technologies in their everyday lives. Working for the European Commission, Ferrari (2013) advances ideas developed from al-Mutka (2011) to construct a framework for understanding and assessing digital competences. Ferrari's work deliberated on competences in the areas of information, communication, content creation, safety and problem-solving. Ferrari's framework on digital media competences was useful in guiding and appropriating the selfassessment of young people's competences to gain insights on their views of their strengths and difficulties confronted in digital media practices today.

\section{Digital Storytelling}

Digital storytelling can be regarded as a form of a digital-era version of participatory practice. Young people today participate in social media, blogs, and YouTube by expressing their experiences, thoughts and private accounts of happenings surrounding them. The individualistic nature of user-created digital stories that often focus on their social experiences more often than not is embroiled in controversies in Malaysia's multifaceted and thorny tapestry of living realities. At the heart of digital storytelling practice in the present study is the focus on digital competences; that is information, communication, content creation, safety and problem-solving skills involved in using digital media tools for creative expression and communication. Several studies have shown that digital storytelling is an effective pedagogical tool to develop digital literacies, especially in cultivating storytelling skills, oral and written communication skills, collaborative skills and critical thinking skills as well as production skills, crafting the stories and understanding the impact of their stories (Dunford \& Jenkins, 2015; Lundby, 2008; Alexandra, 2008).

\section{METHODOLOGY}

The study adopted an exploratory approach that provided valuable, quality information on young people's media competences. A mixed-method that advanced the systematic integration of quantitative and qualitative approaches was used in a study from June 2015 till October 2019. Questionnaire surveys on self-assessment of digital competencies were implemented to examine digital media activities and skills in five areas, namely information, communication, content creation, safety, and problem-solving. The findings reported here are part of a bigger study that examined digital competences of 1200 young people in 12 secondary schools in Malaysia. In this article, the findings of 191 participants who completed self-assessment surveys as well as digital storytelling activity are presented. The 191 participants joined in digital storytelling, a workshop-based process where participants used tablets and mobile phones to tell stories about cyber problems. The structured and facilitated workshops employed focus group discussions and production skills with an emphasis on digital media competences to spark conversations about creating and sharing stories in critical, creative and mindful ways. 


\section{RESULTS AND DISCUSSION}

The first part of this section of the article offers insights on demographic data on the 191 respondents. The second part reveals insights into the self-assessment survey with regard to digital competences of respondents in the fields of information, communication, content creation, safety, and problem-solving. The third part offers respondents' views on digital competences and literacy in approaching digital storytelling as participatory media practice.

1. Key Characteristics of the Respondents

This section offers insights into the respondents of the study to give a general understanding of media practices among young people.

Table 1: Demographic data of respondents $(n=191)$

\begin{tabular}{|c|c|c|}
\hline Item & Demographic & $\mathrm{N} /(\%)$ \\
\hline \multirow[t]{2}{*}{ Gender } & Male & $85(44.5)$ \\
\hline & Female & $106(55.5)$ \\
\hline \multirow[t]{5}{*}{ Ethnic Group } & Malay & 124 (64.9) \\
\hline & Chinese & 19 (9.9) \\
\hline & Indian/ Punjabi & 17 (8.9) \\
\hline & $\begin{array}{l}\text { Indigeneous Group } \\
\text { (Kadazan, Iban, etc) }\end{array}$ & $21(11.0)$ \\
\hline & Dayak & $10(5.2)$ \\
\hline
\end{tabular}

2. Competences of Young People in five Domains: Information, Communication, Content Creation, Safety, and Problem Solving.

A self-assessment exercise was conducted where the respondents were asked to indicate their digital competences on a scale of $1-4 ; 1$ as least capable, while 4 as most capable. The findings suggested that the respondents generally thought that they were proficient in many skills. The respondents noted that while they were generally capable when working with information, and moderately capable of communication and safety, there were still some activities that they struggled within these domains. The major difficulties, as noted by the respondents fell in content creation and problem-solving domains.

The findings of the young people's self-assessment on their competencies are summarised below.

Table 2: Overall Skills $(n=191)$

\begin{tabular}{lcc}
\hline \multicolumn{1}{c}{ Sections } & Mean & Std Deviation \\
\hline Information & 3.19 & 0.74 \\
Communication & 2.87 & 0.85 \\
Content Creation & 2.38 & 0.86 \\
Safety & 2.96 & 0.86 \\
Porblem Solving & 2.75 & 0.82 \\
\hline
\end{tabular}

\section{a. Information}

On a scale of $1-4$, the respondents stated that they were skilful in storing and retrieving information and browsing, searching and filtering information but less skillful in evaluating information. The findings of the data are presented in detail in the tables below. 
Table 3: Information Theme $(n=191)$

\begin{tabular}{lccc}
\hline & Sections & Mean & Std Deviation \\
\hline Information & 3.19 & 0.74 \\
\hline
\end{tabular}

Table 4: Information Theme Indicators ( $n=191)$

\begin{tabular}{lcc}
\hline \multicolumn{1}{c}{ Sections } & Mean & Std Deviation \\
\hline Browsing, Searching and Filtering & 3.23 & 0.70 \\
Information & 2.99 & 0.75 \\
Evaluating Information & 3.35 & 0.76 \\
\hline Storing and Retrieving Information & & \\
\hline
\end{tabular}

\section{b. Communication}

On a scale of $1-4$, the respondents thought that they were competent in social interacting through technologies, but less so in sharing information and content, engaging in online citizenship, collaborating through digital channels, netiquette and in managing digital identity. The detailed features of competences in the communication domain are unveiled in the tables below.

Table 5: Communication Theme $(n=191)$

\begin{tabular}{lcc}
\hline Sections & Mean & Std Deviation \\
\hline Communication & 2.87 & 0.85 \\
\hline
\end{tabular}

Table 6: Communication Theme Indicators $(n=191)$

\begin{tabular}{lcc}
\hline \multicolumn{1}{c}{ Sections } & Mean & Std Deviation \\
\hline Interacting Through Technologies & 3.35 & 0.73 \\
Sharing Information and Content & 2.83 & 0.84 \\
Engaging in Online Citizenship & 2.82 & 0.84 \\
Collaborating Through Digital Channels & 2.85 & 0.86 \\
Netiquette & 2.78 & 0.91 \\
Managing Digital Identity & 2.61 & 0.91 \\
\hline
\end{tabular}

\section{c. Content Creation}

The respondents noted that they were not that capable in content creation, specifically in developing content, integrating and re-elaborating content. In addition, they were seen as less capable of understanding issues on copyright and licenses as well as programming.

Table 7: Content Creation Theme $(n=191)$

\begin{tabular}{ccc}
\hline Sections & Mean & Std Deviation \\
\hline Content Creation & 2.38 & 0.86 \\
\hline
\end{tabular}

Table 8: Content Creation Theme Indicators $(n=191)$

\begin{tabular}{lcc}
\hline \multicolumn{1}{c}{ Sections } & Mean & Std Deviation \\
\hline Developing Content & 2.75 & 0.85 \\
Integrating and Re-Elaborating & 2.64 & 0.85 \\
Copyright and Licenses & 1.93 & 0.84 \\
Programming & 2.21 & 0.91 \\
\hline
\end{tabular}




\section{d. Safety}

In this domain, the respondents held that they were capable of protecting the health and personal data but less so in protecting devices and the environment. They were confident in their ability to protect their online personal data from being used by other parties. Interestingly, the respondents indicated that they were quite capable of knowing how to protect themselves from cyberbullying and in knowing how to block unhealthy content published on the Internet.

Table 8: Safety Theme $(n=191)$

\begin{tabular}{lccc}
\hline \multicolumn{1}{c}{ Sections } & Mean & Std Deviation \\
\hline Safety & 2.96 & 0.86 \\
\hline & & \\
\multicolumn{1}{c}{ Sections } & Table 9: Safety Theme Indicators (n=191) & \\
\hline Protecting Devices & Mean & Std Deviation \\
Protecting Personal Data & 2.51 & 0.97 \\
Protecting Health & 3.16 & 0.80 \\
Protecting the Environment & 3.19 & 0.87 \\
\hline
\end{tabular}

\section{e. Problem Solving}

In this domain, the respondents appeared to indicate that they were quite capable of identifying needs and technological responses, innovating and creatively using technology and identifying digital competence gaps; however, they appeared less capable of solving technical problems.

Table 10: Problem Solving Theme $(n=191)$

\begin{tabular}{ccc}
\hline Sections & Mean & Std Deviation \\
\hline Problem Solving & 2.75 & 0.82 \\
\hline
\end{tabular}

Table 11: Problem Solving Theme Indicators $(n=191)$

\begin{tabular}{lcc}
\hline \multicolumn{1}{c}{ Sections } & Mean & Std Deviation \\
\hline Solving Technical Problems & 2.40 & 0.92 \\
Identifying Needs and Technological & 2.93 & 0.71 \\
Responses & & 0.83 \\
Innovating and Creatively Using & 2.78 & 0.82 \\
Technology & 2.89 & \\
Identifying Digital Competence Gaps & & \\
\hline
\end{tabular}

In summary, the findings above revealed that Malaysian young people thought that they were capable of searching, evaluating and managing information. The respondents believed that they could interact with new technologies when it comes to communication as well as protect personal data and health (blocking unhealthy material and managing cyberbullying) in the field of safety. However, they held that they encounter difficulties in developing content and understanding issues related to copyright and programming.

The findings suggest that spending time online did not mean that young people were developing digital media literacy competencies. It is crucial that policy-makers and relevant stakeholders design programmes that will inculcate knowledge and competences in different areas to ensure that young people can be media literate and be productive knowledge consumers and creators. 
3. Digital Storytelling

In this activity, participants were required to produce 1-3 minute screen stories on issues like cyberbullying, online scams, online safety, privacy, online dating, managing online emotions and fake news. The process of planning, searching for information and organising of ideas through photographs, images, storyboards, writing scripts and performing in front of the camera were important competencies that were observed. The participants used mobile handphones, tablets, visual and audio editing software to finish their stories.

It is also helpful to point out here that the workshop facilitators, in some cases, had to painstakingly motivate the participants to be creative and authentic instead of copying works from the web. Having these digital activities also enabled the facilitators to get a feel of the participants who did and did not understand the information that they saw and read on the Internet. Interestingly, the participants in these activities did a presentation on the final day of the workshop where school principals and teachers were invited to view the digital stories. The school authorities were pleasantly surprised and uploaded the creative works on the school website and YouTube. As authors of their own work, all participants were able to present their stories for critical inquiry, self-reflection, and creative expression. The key experiences, thoughts, and struggles confronted in the digital media literacy activities raised in the conversations concerning the five competence domains, i.e. namely information, communication, content creation, safety, and problem solving are presented in the following section.

\section{a. Information}

In this domain, the digital competences encompassed browsing, searching and filtering information; evaluating information; and storing and retrieving information. In retrieving the information to develop short video clip(s) as group work, the participants relied on inspiration derived from their search on Google and browsing YouTube. The information obtained mainly from these two resources not only gave them new ideas but also enhanced existing ideas to enable them to complete the digital storytelling activity. YouTube was particularly popular among these participants as it presented various examples of how sound and effects could be integrated into their video stories. As observed by one participant,

Erm... I take it mostly from Google and it inspires me and we create our own ideas too and also there are some YouTube videos we watched and we get our plans, how to do the effects there and the sound and the app (SDMS2)

In developing short video stories, one participant used Adobe Premiere to edit the video. Having discovered and experimented with it before the workshop, the participant decided to use this software for purposes of video editing. This participant also believed that using this software would result in a better quality video. In describing the use of the software, this participant explained,

Adobe premiere to me is a... it's a software where you can like... it is hard to use, but if you know how to use it you can get a better result at the end of the video. So I discovered Adobe Premiere through YouTube videos, I used to do a lot of like video editing so I wanted to find a software that could fulfill what I want, so I choose Adobe Premiere (GRSR3) 
In addition to using Google - View All or YouTube to search for information, some participants navigated for information through the use of Google - Image. These participants used Google - Image to search for the themes assigned to them; because using Google -View All to search would result in largely English based textual information. They experienced difficulties to comprehend the textual information as English was not their commonly used language. Finding information using Google - Image thus, enabled them to understand the information visually to aid their understanding of the information related to the assigned theme. However, they encountered problems to ensure that the information obtained was reliable, as one participant explained,

search-kan... Kan saya search tajuk kami - cyberbullying, so everything yang kami search itu English, so lebih mudah untuk kami cari dia punya meaning dalam Google - Image. Firstly, cari maklumat itu, tak sure samada reliable, kami share it guna Wikipedia. Cari dulu maksudnya and then kami search guna Google - Image. Kami cari apa itu contoh-contoh dan apa itu cyberbullying dan action of cyberbullying (SSR4)

The views of respondents depict the obstacles participants confronted in information navigation. Given that the bulk of the information was found in the English language, some of them had to grapple with the information and resolved to search for images. Interestingly, identifying different types of information was difficult given the language issue. There were some issues in deciding on keywords for online search and some of them did not obtain the information that they were looking for. Wikipedia was seen as the 'first go to source' for reliable information. The views of the participants on the complexities in searching for information revealed that the competences in this domain were fraught with problems.

It was revealed that many participants found it difficult to evaluate the truthfulness of information obtained from the Internet. Participants often associated the truthfulness of information with its sources, with Wikipedia being perceived as a reliable source. A participant said that a piece of information could be considered truthful "if it came from Wikipedia, as it can be a trusted source" (GRSR1). Another exchange with the participants illustrated their dependence on Wikipedia when searching for information.

Q1: Laman page mana yang paling you percaya?

R4: Wikipedia.

Q1: Wikipedia memang betul semua?

R4: Tidak semua tapi dapat percaya sikit. Ada bahan rujukan.

(GRSR4)

Apart from Wikipedia, the participants seem to view what they see on television as verified information. For instance, a participant explained that Lazada is considered a trustworthy website, unlike Instagram, because it has appeared on television (SMSR1), while another participant claimed that "television news basically shows the reality" (MPR5).

Some of the participants expressed their concern over relying on a single website or websites and social media such as Facebook, WhatsApp, and Google because the information could be "fake" (MPR5). As stated by one respondent, "a person stole the idea from someone else... [but remove] the watermark and they use their name on it" (GRSR1). They felt that 
there was a need to cross-check information from multiple websites to determine their reliability and truthfulness.

The difficulty in evaluating internet information also shown in their explanation of what made a website authoritative. Web addresses that consist of "dot com", "dot my", and "dot org" (SSR1) or even "www dot" (BKMR6) were believed to be reliable. When asked how useful websites were selected, a participant said that he would choose one that had advertisements (BKMR4), while another participant said he would "choose... from the top of the Google [search results]" (SDMS4), thus showing an absence of critical assessment of the information they encountered in digital media.

In addition, it appeared that the participants had no knowledge of questioning online and media information - questioning who created the information and media content, why it was created and whether it was credible to enable participants to make decisions.

Generally, participants noted that they seldom were involved in investigation skills and did not question many things in their daily lives. Questioning online information and the media was deemed as a non-issue and they were not encouraged in school settings into thinking about such matters.

\section{b. Communication}

This domain includes competencies like Social interaction through technologies; Sharing information and content; Engaging in online citizenship, Collaborating through digital channels, Netiquette and Managing digital identity.

The participants of the workshop stated that there were many avenues for online communication and social interaction. The participants were asked about digital citizenship and whether they would share the digital stories they designed and developed to raise awareness on communication problems confronted by young people today. Some participants agreed that it was important to share the information with their friends. They believed that it was important to share to make their friends aware of the current issues affecting them. One participant who worked on a story on cyberbullying remarked, aku."

Mungkin depa akan terfikir macam tu dan depa takkan buat lagi (TKP S4).

The digital storytelling activity provided the participants with the opportunity to interact socially with other participants from diverse communities using digital technologies. One group of participants considered this diversity as a good experience when they watched and discussed screen stories created by project participants from other states and schools. According to one participant,

Of course yes because we can see even in here... we are full of diverse communities so doing a short story and sharing with different communities is a very good experience for me (SDM S3)

The interaction among the diverse participants in one group also provided them with the opportunity to share one another's cultures and learn phrases in a new language. This diversity was not a hindrance to these participants to work together during the workshop on the assigned activity. One participant remarked, 
Bagi saya, perkauman tidak menjadi halangan untuk kita berinteraksi among members online atau offline. Kalau kita duduk dalam satu keadaan yang mempunyai banyak kaum, for me, it is not a halangan but kita boleh tau culture mereka dan sebagainya. Even though mereka bercakap sesama mereka, at least kita dapat tahu sedikit words. (GRS R3)

However, there were difficulties with communication when netiquette was not observed. One participant shared experience of having her own photo uploaded without permission. This experience made her feel that seeking permission was important especially when the photo that was uploaded became an object of online comments in a language that she did not understand. The participant remarked,

She took the photo okay, for me it is okay but I don't like one thing that is... she laughed at it.... I was a little bit (hurt)....Yes, because my friends... they did that to me. She did post my picture on WeChat...Yeah and then she typed in Chinese something and the people who replied also type in Chinese something, I don't understand and then I just let it be....I did ask her but she didn't say anything to me...... don't understand what she typed inside the phone (text) so I just left and I also scolded her saying why did she post my photo without my permission and she just smiled (GRS R5)

On the whole, the conversations revealed that the participants generally were able to interact with people from diverse communities, but responsible communication was needed where users respect the multiple views and manage their comments and posts in sensible ways. Many of the participants believed that young people should learn about good habits, actions, and usage of the digital platform to manage their digital self-identity. They noted that they were capable of finding relevant communities that suited their interests but sometimes were not so sure about netiquette rules when communicating online with cyber communities.

Engaging in online citizenship appeared as another gap in school settings where little was deliberated on this topic. Many of the participants had not thought much about their roles in digital citizenship and the purposes behind the digital storytelling activity. While many of them had experienced cyberbullying or had friends who encountered these problems, they felt that they had inadequate knowledge on attending to these social matters.

The participants were asked to share their digital stories with friends to contribute to online discussion. Apart from getting 'likes' and some comments, they felt that there was not much online discussion on the issues. However, various benefits were mentioned in sharing the digital stories created by the participants. The participants stated that sharing digitally was more effective and it would help create awareness among social media users to become more responsible users. One participant noted,

Generally, Malaysian people don't like to read much. They only like social media like Instagram. They like to post stuff and get Likes. But they don't know about cyberbullying. They don't know what to do if they are get bullied on the internet. So we, as students, we should bring awareness today. We should post good stories on social media to help them (SDMS4) 
Through their digital storytelling works, some of them expected to contribute to the digital citizenry. The excerpts below are samples of the participants' expectations of positive digital citizens among young people.

Yes, of course I do expect some change so that social media would be better place and I think through the stories that we created, uh... it would help others-lah... like spread awareness and yeah, make them into a better person and make them to know, to realize what to post and what not to post online (SDMS8)

I do look forward to see the change because most probably sometimes a person don't know that he is cyberbullying a person because they think that it's a joke and then, the person could understand the joke but the person is actually being stressed and having depression because of the message that the guy sent. So it's actually good to bring awareness (SDMS4)

The participants observed that they needed more knowledge in understanding online citizenship. The importance and potential influence of support mechanisms in advancing digital media literacy or online citizenship were not adequately discussed in many schools in Malaysia.

\section{c. Content Creation}

This domain included competences like developing content, integrating and re-elaborating, knowledge on copyright and licenses and Programming. In completing the given digital storytelling activity, the participants used various devices and applications. While some of them did not have enough knowledge, they used devices such as a tablet, mobile phone, laptop, drawing and editing software to complete their work. Some of their comments are as below,

Then last night because I don't like the video pictures that are mixed up, so I want perfection so I just downloaded an app that shows how to draw the eyes, how to draw the body part and anything, I just sketch it out and then I draw it back in my handphone.... (GRSR1)

The use of various media in the process of completing the tasks helped the students to develop digital competence and storytelling. The participants had the opportunity to learn and utilise digital skills such as downloading the photo, adding text, video editing, and using audio editing software, as mentioned in the excerpts below:

And also I've learned much things about video editing. My friend taught me. So I'm happy through that. Maybe I could bring up this thing further (SDMS1)

Gembira kerana dapat hasilkan video...Seperti apps yang boleh edit, cut bagi video tu bagi jadi pendek dan buat masuk video tu boleh jadi kalau dua video boleh jadi boleh gabung satu (TKPS1) 
Apabila saya membuat video dengan sendiri, baharu saya tahu susah juga membuat video ini. Lebih-lebih lagi dalam video untuk filem di pawagam, itu lagi susah kerana lama. Yang ini seminit ini juga ambil masa dua jam lebih. Oleh sebab itu, saya juga dapat belajar bagaimana hendak edit suara dan sebagainya... juga belajar edit video dengan lebih baik (PMTR1)

The participants made digital stories in groups. Working together with members of the groups enhanced their self-performance and digital media competences. The participants mentioned the development of self-discipline, working together, and having a sense of respect for members of the group. While working together as a team, they needed to listen to and respect every member's views. They also used digital platforms and applications to make their stories interesting. They also added that these creative skills for content creation were useful for their personal, career and social purposes. The following excerpts illustrated these points.

At first, we were afraid of whether we can do this... because we don't know many things... but we learnt new things. Yes, were successful and became creative, obviously because when we use as many media as we can... so we really can develop ourselves; self-discipline as well lah. So, yeah, we get a very new experience working together to do a video storytelling so actually really help learning about creativity. I hope it will help my future (SDMS3)

Yes, I think by using the digital media, I improved my self-performance and expression because I can use the internet to look for extra information, to look for information for my studies and use pictures, logos, icons...so that I produce stories better (SDMS3)

The descriptions above noted that while the participants had doubts about their creative competencies at first, they were willing to learn and were happy to do acting, filming, editing, directing and sound mixing. With guidance from the facilitators, they were competent in using different media forms and devices in putting together a story creatively.

Copyright and license issues emerged as problematic in the conversations with the participants. Some participants believed that if they did not make money from using the original creation, it was not necessary to request permission for copying the materials and using them in content creation. Also, thought that if the creators shared something on the internet, this meant that they actually allowed the public to use their creations. The excerpts below are samples of responses of participants.

Aware about copyright, rules and law in Malaysia? Yes and no. But I do think ...that when you put in the song in your video, we should give credit to the owner but we don't have to ask for permission because we are not making money with it (SDMS4)

Selalunya orang yang bubuh dalam Google ni dia nak bagi kita pinjam dan bagi idea lah, kongsi dengan kita (TKPS1) 
In relation to the knowledge of rules and right related to content creation, the participants did not know how to acknowledge the sources.

Tak tau nak bagi perhargaan macam mana... (TKPS4)

Plagiarism? I have no idea (BKMR4)

The study revealed that many participants did not take copyright issues seriously because there was a lack of awareness and schools or parents did not delve in these issues with the young people. This digital storytelling project which enabled participants to work on visual and audio materials triggered their thoughts on media law, rights, and rules when working with materials taken from the Internet.

\section{d. Safety}

This domain encompasses competences like protecting devices, protecting personal data, protecting the health and protecting the environment. During the project, the participants logged in various sites to search and download information and materials. However, while the majority of the students' responses indicated that they were aware of the need to logout from the devices they had used, some believed that if they login as guests, it was not necessary for them to logout. The experts below are samples representing their responses.

Logout lah takut orang lepas ni guna ke so yang penting logout lah sebelum keluar daripada makmal ke apa (TKPS6)

For the Chrome Book, I didn't logout because it is in guest mode (SDMS6)

Clearing footprint such as history seemed to have gathered mixed feedback from the participants. Some participants lacked knowledge of what was footprint history and the need to take cautionary measures in this matter. They asserted that they did not know about footprint; they thought that the tablets would clear the footprint itself and their use of the sites would not be recorded and could not be tracked. The responses below are excerpts on digital footprint:

Digital footprint, cybercrimes...nak block.... (GRSR3)

Mungkin komputer ini clear sendiri. Nak block benda tak baik itu...tak pasti (GRSR4)

Whatever I do such... as YouTube, Facebook, Google and other search, the history is never there. I don't block unhealthy content if it pops up. (MPR3)

Some participants are of the view that blocking unhealthy content published on the Internet and that clearing history was not important if they did not search for any prohibited materials, they did not mind others viewing their history, as indicated in the excerpt below.

I did not block. I did not clear because I did not search anything wrong and anyone is free to search for history...be glad (free) to do so. (SDMS5) 
Overall the data indicated there was a major lack of knowledge related to safety, specifically in addressing one's digital footprint, knowing when to avoid activities that are considered cybercrimes and blocking unhealthy content on the Internet. The participants also did not have much to comment on protecting the health and protecting the environment. Many of them were not sure of these areas of knowledge that affect them in terms of excessive use and in terms of using digital gadgets which could be implicated in environmental dangers.

\section{e. Content Creation}

The participants' competence in problem solving was explored in terms of their ability to identify needs and technological responses, innovating and creatively using technology in completing their digital storytelling project. In this particular project, the way they worked in groups to choose the best solution to accomplish the tasks, and the extent to which they created thoughtful explanation with the support of digital applications in communicating a message was taken into consideration.

Most of the participants explained that they used specific digital tools to source materials and information in order to complete the assignment. For example, one group looked for suitable music on Facebook (SSR5), and another group downloaded images to a mobile phone before transferring them to the tablet that was provided by the researchers (PMTR6). Google and YouTube were two other popular means of searching for information and ideas. Some participants talked about learning how to do things on the Internet:

Kita perlu membuat video itu so, kita hendak mencari information atau ideas. Kita tengok blog orang yang pernah buat seperti short film. (PMTR6)

Di YouTube saya lihat bagaimana untuk menggerakkan grafik, icon dan animasi itu. (MPR6)

In order to produce the videos, the participants had to select appropriate software and applications. Ease of use and familiarity were two common reasons given by the participants:

Lebih cepatlah lebih senang. Application yang saya guna itu lebih senang, lebih cool lah. (SSR5)

Mungkin sebab saya lebih biasa kepada apps itu dari notebook sebab saya sudah lama guna itu - instashot. (TSR5)

For some, the experience of using technologies helped them to reflect on their own digital competence. Many of them realised that the handling of digital tools and applications was more difficult than they thought. In the process, some of them also found out that they lacked technical skills in accomplishing their digital projects. For example:

Kadang-kadang lukis memang begitu tapi kalau di tab, terus dia macam pergi tempat lain. (TSR2)

Lepas itu mahu buat poster itu kena banyak bersabar sebab ada yang salah sikit terus kena ubah lagi. Terus idea macam, eh terkurang idea kena tambah lagi, kena fikir lagi dalam projek digital ini. (TSR4) 
Seperti video, kita perlu banyak kali shoot kerana banyak kali salah. Kita membuat pembulian siber so, komen-komen dalam group ada negative itu. Jenis video kita adalah bertampal, so ada yang sehingga terbalik dan terpaksa cancel untuk buat yang baharu. Selepas itu, dengan penggunaan edit itu perlu betul. Kalau filter video kita itu tidak berapa okay, so kita tidak boleh menampakkanya jelas dengan gambar dan sebagainya. Muzik juga memainkan peranan kerana kita boleh menyentuh perasaan orang. Kalau muzik juga muzik rock, ia tidak boleh masuk dalam jiwa seseorang itu. (BKMR6)

To manage the story telling project, some participants took the initiative to set up chat groups on the mobile phone so that group members could discuss their tasks after school.

Kami buat group di WhatsApp saya invite mereka semua then kami bincang sudah buat dia punya lakar-lakar, gambar suruh mereka baca faham dulu supaya esok tidak lagi kelam kabut. (TSR2)

When asked how they worked together to accomplish the stories, the participants said that they either "mixed the ideas of everyone" because "the chemistry of the team is better than the individual" (PFSPR6) or they discussed with group members which idea to adopt (TSR5; SSR2). A participant said that his group members complemented one another because each had his/her own weaknesses (GRSR6), while another participant explained how they resolved their differences through negotiation:

Dari segi berjaya, video itu kita buat sehingga kita pass. Kalau dari segi cabaran itu, banyak cabaran. Contohnya, dalam itu kadang kala kita salah faham. Ada juga yang hendak mengikut idea dia dan ada yang hendak ikut idea lain. So, kita selesaikan dengan mencampurkan idea kita. Selepas itu, kita bincang dalam satu group tentang idea itu. Contohnya, saya lakarkan idea. So, saya kata, "Kamu semua buat penambahbaikan." So, mereka buat tambahbaik pada idea itu. Itulah idea kita. Maknanya kita semua setuju dengan apa yang ada. Itu cabarannya. So, kita buat bersama. (BKMR5)

This episode shows that the group engaged in an active process of reflection and reviewing their work when completing the assignment. Such a practice was indicative of a good attempt at problem solving.

Although in general the participants claimed that they worked together during the workshops, there were times when there was a lack of discussion and negotiation among group members. While most of them were in control of their own parts in the project, decisions were often made by a few dominant individuals in the group.

The participants were asked whether they deliberated on responsibility in their work. A participant said he took into consideration other people's views and privacy while taking photographs for the project (TSR6). Another participant explained that the group screened the images that its members had found online and if the members were not sure whether an image was offensive they would consult the facilitator (BKMR6). 
In general, with the help of guidance from the facilitators, the participants attempted to make thoughtful stories in the hope of addressing social difficulties. In doing so, many of them were able to gather appropriate information using digital tools and present thoughtful understanding about the topics that were given them. In some instances, they encountered problems in their projects, but the conversations in focus group discussions opened pathways for reflective thinking and practice, making this project a huge success.

\section{CONCLUSION}

Livingstone (2014) argues that digital media literacy contributes to a full and meaningful life and is important for a skilled, creative, and ethical society. Digital media literacy is essential to empower young people to critically evaluate the information they access, to enable them to better understand the materials they need and the meaning they convey as well as to respect diverse views and to take responsibility for their online actions. The present study found that many young people are quite confident in the ways they communicate and manage digital media activities but are probably unaware of the biases inherent in the information they search, create and communicate in a fast evolving world. The notion that digital natives are not digital literates is one that we have to consider seriously in light of some of the young people's thoughts and practices on digital media.

Digital storytelling has the potential to foster digital competences and civic engagement and can cultivate intellectual and creative curiosity through media literacy. Digital storytelling creates a user environment where young people not only produce focused stories in technology-oriented spaces but also learn to live better as productive contributors for an informed, creative, and ethical society.

The place of digital media literacy as a broad context - consisting of cognitive, technical and ethical dimensions in the Malaysia education setting has been a slow process. A national digital media literacy programme that advances digital storytelling is an essential step in addressing initiatives that aim to enhance young people's media practice. Continuous dialogue, policy support, and research activities must persist to create a digital media learning environment where young people can access, understand, evaluate, collaborate and create lifeworld experiences in holistic ways. 


\section{ACKNOWLEDGEMENT}

This project was supported with grants from Malaysian Communications and Multimedia Commission -304/PPSENI/650761/S129 and UNIMAS - F09/SpTDG/1730/2018

\section{BIODATA}

Ambigapathy Pandian is a Professor at the Faculty of Language and Communication, Universiti Malaysia Sarawak (UNIMAS). His research interests include language and literacy education, teaching English to speakers of other languages, sociolinguistics, multiliteracies and higher education. Email: pambigapathy@unimas.my

Shanthi Balraj Baboo is a Professor at the School of the Arts, Universiti Sains Malaysia (USM). Her works aim to enhance children and young people's empowerment in contemporary communities, specifically in digital media literacy. Email: shanthibalraj.usm@gmail.com

Lim Jing Yi is a lecturer at School of the Arts, Universiti Sains Malaysia (USM). Her research interests include digital competency and society and visual communication design. Email: gene.limjingyi@usm.my 


\section{REFERENCES}

Ala-Muta, K. (2011). Mapping digital competence: Towards a conceptual understanding. JRC Technical Notes. European Commision. Luxembourg, European Union.

Alexandra, D. (2008). Digital storytelling as transformative practice: Critical analysis and creative expression in the representation of migration in Ireland. Journal of Media Practice, 9(2), 101-112.

Cohen, J. N., \& Mihailidis, P. (2013). Exploring Curation as a core competency in digital and media literacy education. Faculty Works: Digital Humanities \& New Media, 4. Retrieved on 2 November 2019 at https://digitalcommons.molloy.edu/dhnm_fac/4

Dunford, M., \& Jenkins, T. (2015). Understanding the media literacy of digital storytelling. Media Education Research Journal, 5(2), 26-42.

Ferrari, A. (2013). DIGCOMP: A framework for developing and understanding digital competence in Europe. JRC Scientific and Policy Report. Spain: European Union.

Guo, L. (2014). Preparing teachers to educate for 21st century global citizenship: Envisioning and enacting. Journal of Global Citizenship \& Equity Education, 4(1), 1-23.

Hobbs, R. (2010). Digital and media literacy: A plan of action. A White Paper on the Digital and Media Literacy Recommendations of the Knight Commission on the Information Needs of Communities in a Democracy. Washington DC: The Aspen Institute.

Johnson, L. (2015). Rethinking parental involvement: A critical review of the literature. Urban Education Research and Policy Annuals, 3, 77-90.

Jones, L. M. (2010). The future of internet safety education: Critical lessons from four decades of youth drug abuse prevention. Publius Project at the Berkman Center for Internet and Society, Harvard University, Boston. Retrieved on 5 Nov 2019.

Juppi, P. (2017). Engagement and empowerment digital storytelling as a participatory media practice. Nordicom-Information, 39(2), 31-41.

Livingstone, S. (2004). Media literacy and the challenge of new information and communication technologies. Communication Review, 1(7), 3-14.

Livingstone, S. (2014). Developing social media literacy: How children learn to interpret risky opportunities on social network sites. Communications: The European Journal of Communication Research, 39(3), 283-303.

Lundby, K. (2008). Digital storytelling: Mediatized stories. New York: Peter Lang Publishing, Inc.

Prasad, N. V., Balraj, S., Pandian, A., \& Nordin, M. Z. (2016) Literacy, skills and perceptions of young children on media matters. Researchers World- Journal of Arts, Science \& Commerce, 7(1), 62-73.

Shanthi Balraj Baboo, Ambigapathy Pandian, Soubakeavathi Rethinasamy, Joseph Ramanair, Chen Siaw Wee, Ntu sss slk Ying, Mohammed Zin Nordin \& Sheila Yvonne (2017). Cultivating productive practices in digital and media literacy among secondary school students in Sarawak. Sustainable Community Transformation, 13(1), 7.

Shanthi Balraj Baboo, Ambigapathy Pandian, Muhizam Mustafa, Mumtaz Begum Backer, llangko Subramanian \& Lim Jing Yi. (2015). Captivated with Facebook: Constructions, contexts and consequences. Media Matters - MCMC: Networked Media Content Research Report, 2, 26-46.

Shanthi Balraj Baboo, Ambigapathy Pandian, Prasad, N. V., \& Aaron Rao. (2013). Young people and new media in Malaysia: An analysis of social uses and practices. Journal of Arts, Science \& Commerce, 4(2), 50-56. 